\title{
Tracing Curiosity with a Value Perspective
}

\author{
Soern F. Menning \\ Faculty of Humanities and Education, Department of Religion, Philosophy and History, \\ University of Agder, Norway
}

\begin{abstract}
Several have challenged the idea that the act of educating is a neutral endeavour. Following this line of thought, this article intends to examine a common concept often taken for granted: curiosity. The aim of this article is to explore the notion of curiosity in an early-childhood-educationand-care (ECEC) context in Norway in order to provide new perspectives on how value aspects of curiosity are communicated in official documents. Four ECEC documents from different organisational levels will be analysed. Informed by qualitative content analysis with a conceptdriven strategy, this document analysis seeks to explore connections between the notion of curiosity and prominent value fields in ECEC, such as competence, democracy and care. Analysis of the documents suggests that curiosity is a value-loaded notion here, one which often has a competence-related value and which is frequently understood as a tool for gaining knowledge, especially in natural science and mathematics. Other value aspects, such as nurturing democracy, are represented to a minor degree. At the same time, the documents do not include possible ethical aspects of curiosity, such as connections to interpersonal caring, nor do they mention any existential or intrinsic value. In the final discussion, the article therefore explores these possible alternatives.
\end{abstract}

Keywords: Values education; document analysis; early childhood education; preschool; kindergarten

Received: August 2016; Accepted: May 2017; Published: September 2017

\section{Introduction}

Curiosity is a complex concept that has been discussed in the field of psychology (Berlyne, 1960; Loewenstein, 1994; Voss \& Keller, 1983), as well as in the fields of philosophy and religion (Martens, 2003; Müller, 1984), and which is also commonly mentioned in educational contexts (e.g. Engel, 2015; Menning, 2016). A

^Correspondence to: Soern F. Menning, Faculty of Humanities and Education, Department of Religion, Philosophy and History, University of Agder, Norway. Email: soern.f.menning@uia.no

(C2017 Soern F. Menning. This is an Open Access article distributed under the terms of the Creative Commons Attribution 4.0 International License (http://creativecommons.org/licenses/by/4.0/), allowing third parties to copy and redistribute the material in any medium or format and to remix, transform, and build upon the material for any purpose, even commercially, provided the original work is properly cited and states its license.

Citation: Soern F. Menning. "Tracing Curiosity with a Value Perspective." Nordisk tidsskrift for pedagogikk og kritikk, Vol. 3, 
recent focus on children's participation in learning and daily life in ECEC, in which curiosity is given a leading role, leads to the need to explore the concept further. In Norway, the Kindergarten Act (Barnehageloven) views curiosity as central to its section on content, stating that "kindergartens shall nurture children's curiosity, creativity and desire to learn, as well as offer challenges based on children's interests, knowledge and skills" (Kindergarten Act, Section 2: Content of Kindergartens).

At the same time, the concept has not been a major focus of educational research (Chak, 2007), which suggests that the concept is taken for granted. ${ }^{1}$ Several researchers in the field of cultural history, however, have described that the construction of the concept is culturally embedded and that the attitudes and value perspectives towards curiosity have changed radically in relation to societal and cultural alterations (Benedict, 2001; Blumenberg, 1988; Kenny, 2004).

The aim of this article is, therefore, to explore the notion of curiosity in an ECEC context in Norway in order to provide new perspectives on how value aspects of curiosity are communicated in official documents. This is especially important as these documents are continually revised and are influential on educational practice. The research question is twofold: What dominant value aspects of curiosity can be traced in a selection of official documents concerning the field of ECEC, both primarily in Norway, but also in a wider international context? Are there any missing value dimensions when considering the roots and changing understandings of the concept?

This article is part of an ethnographically informed project on the study of curiosity from a value perspective in an ECEC context in Norway. While other parts of the project concentrate on preschool teachers' reflections on the concepts and their practices, this article focuses on those social-political arrangements brought to the site of practice in the form of official documents (Kemmis, Wilkinson, Edward-Groves, Hardy, Grootenboer \& Bristol, 2014, p. 38). The study is positioned in the research field of values education. Values education understands education as a value-based discipline in which values become visible in attitudes and daily practices (Biesta, 2009, 2010a, 2015; Emilson \& Johansson, 2009; Swanson, 2010; Thornberg 2014). ${ }^{2}$ There are several approaches to the concept of value (Van Deth \& Scarbrough, 1998, pp. 21-47). This study is based on a social constructivist epistemology, whereby values can be seen as collective agreements forming the basis of human action and how human action is assessed (Halstead \& Taylor, 2000; Johansson, Fugelsnes, Mørkseth, Røthle, Toftelamd, Zachrisen, 2015).

\section{Changes in the value aspect of curiosity}

The etymological roots of the term curiosity (Latin: curiositas) can be traced back to the Latin words cura, which means care and attention, and curiosus, meaning careful,

\footnotetext{
${ }^{1}$ For example, a commonly used dictionary in Norwegian teacher education does not explain the concept at all (Bø \& Helle, 2008).

${ }^{2}$ For a discussion on the relationship between values and educational practice see also Afdal 2014, p. 48-49.
} 
attentive, inquisitive but also concerned (Pons, n.d.). In the Norwegian language, the equivalent term is nysgjerrighet ${ }^{3}$ which is linked to the German term Neugier and literally translates as craving/greed for the new. In the field of psychology, curiosity is often understood as a neutral trait or state. It can be examined for its necessary preconditions, such as complexity and novelty, with the aim of developing theories about its origin or how to measure it (Berlyne, 1960; Litman \& Jimerson, 2004; Loewenstein, 1994; Loewenstein \& Markey, 2014). In the field of early childhood research, curiosity has often been described as an ingredient in cognitive development and observed as exploratory behaviour (Chak's 2007; 2010; Piaget, 1969). Common to these psychological approaches is that they regard curiosity as a neutral concept and divide it into subcategories, such as epistemic, perceptual or diverse. On the other hand, several authors from other disciplines point out the historical dynamic of the concept (Benedict, 2001; Blumenberg, 1972; Kenny, 2004; Zuss, 2012). For this reason, I wish to present a short overview of how the moral status and values associated with curiosity have changed in different contexts.

Concepts overlapping with curiosity can be traced back to ancient philosophy. Aristotle described "a desire to know" as an intrinsic and non-instrumental love for knowledge (Martens 2003, p. 33-50). In comparison to the positive understanding of curiosity often represented in today's educational settings, Early Christianity had quite a different relationship to curiosity (curiositas). The concept was used to describe a human vice, such as in Augustine's elaboration on the negative content of curiosity in his description of it as the lust of the eyes or the love of knowing solely for the sake of knowing (Martens, 2003, p. 59; Ramos, 2005). In turn, the medieval Scholastic Aquinas differentiates the positive studiositas from the negative curiositas and its superficial approach to knowledge (Ramos, 2005). This morally negative status is still evident in daily language in phrases such as "curiosity killed the cat". 4

Within the scientific approach of the Enlightenment, the concept is taken up again, for example by Francis Bacon, who claimed it to be the starting point for all scientific discovery (Martens 2003, p. 73). Curiosity therefore became a key concept of modernity, which attempted to jettison its negative moral dimensions (Blumenberg, 1973; Müller, 1984). In his book About wondering - the return to curiosity, ${ }^{5}$ Martens (2003, p. 73) claims that during this transition, an instrumental value was, therefore, also attached to the concept of curiosity, resulting from the fact that the aim of scientific discovery based on curiosity was for the benefit of society.

At the same time, the concept is also used with a political and democratic dimension, implying that curiosity includes questioning existing societal patterns and power structures (Foucault, 1985, p. 8; Luebbe 1980, p. 56) and is described by Paulo

\footnotetext{
${ }^{3}$ Although they are not $100 \%$ equivalent, for the sake of the analysis, no difference is made between the translations. For an overview of the different etymological developments in European languages and history, see Kenny (1998).

${ }^{4}$ An example from the Scandinavian languages would be "nysgjerrigper/nysgjerrig Peer", which describes an inquisitive person in a condescending way.

${ }^{5}$ Original title: Vom Staunen - oder die Rückkehr der Neugier.
} 
Freire as an important element of liberating pedagogy (1998, p. 44). An example of this liberating association can also be found in Vladimir Nabokov's description of curiosity in his political and philosophical novel Bend Sinister as "insubordination in its purest form" (1947, p. 46). This short, and by no means complete, overview ${ }^{6}$ shows that the term has been attributed with a range of notions and values and that an overall neutral understanding should not be taken for granted.

\section{Wonder and curiosity - a possible differentiation}

In Norwegian early childhood pedagogy, a concept often closely connected to curiosity is wondering (undring) (Amundsen, 2013). Greek philosophers used the term thaumazein when describing a desire to think about the world (Martens, 2003, p. 33). This may be seen as one of the roots of the concept of curiosity, but it is normally translated with the term wonder. Aristotle describes thaumazein as the starting point for all philosophical actions and sees this as exclusively positive, as he believes it to be the first step towards knowledge (Martens, 2003, p. 33-50).

Opdal (2001) portrays wonder and curiosity as perspective development in education and makes a differentiation between wondering and being curious. He attributes wondering with the power to look beyond existing structures, while proposing that curiosity always looks for solutions within a given structure. In his book The Philosophy of Curiosity, Inan (2012) also differentiates wondering from curiosity and describes wonder as closer to astonishment and admiration: "Wonder, if taken to mean astonishment, admiration, and awe, does not provide the required impetus to do philosophy; only when such attitudes motivate us to become aware of our ignorance that leads into curiosity do we get motivation to inquire into the unknown" (p. 182). Wonder and curiosity are often seen to be closely connected, but as Fuller (2006, p. 8.) points out, wonder could be understood as more passive whilst curiosity involves an active approach to interacting with and wishing to understand the world around. While wonder has been the subject of some investigation in an ECEC context (e.g. Amundsen, 2013; ${ }^{7}$ Griffith, 2014), curiosity seems less explored in a broader sense as part of a normative pedagogical endeavour.

\section{Material}

I have chosen four official documents for closer analysis of the various value aspects of curiosity in an ECEC context. ${ }^{8}$ These documents come from different organisational levels.

\footnotetext{
${ }^{6}$ For a similar overview see also Menning (2016).

${ }^{7}$ Amundsen (2013), pp. 15-90, presents an overview on perspectives on wondering and children's wondering.

${ }^{8}$ The two white papers (Stortingsmelding 41, Stortingsmelding 24) exist only in Norwegian and the quotes are translated by the author. The Kindergarten Act and the Framework Plan for the Tasks and Contents of Kindergartens have official English translations. The OECD document was originally published in English. The recent white paper Tid for lek og lering (Time for Play and Learning) (St. meld
} 
To incorporate an international perspective, the first document included is the OECD document Starting Strong III: A Quality Toolbox for Early Childhood Education and Care (OECD, 2011). In this document, an international group of chosen specialists present a view of how the member states of the Organisation for Economic Co-operation and Development (OECD) should focus their efforts to achieve what is described as high quality in ECEC. This document is not legally binding, but can, through its influence on national policymakers, be described as soft governance and is, therefore, part of the discussion about quality of education (Lawn, 2006).

Furthermore, two national political documents are analysed. These are Stortingsmelding 41 - Kvalitet $i$ barnehagen (White Paper 41 - Quality in Kindergarten) (St. meld. nr. 41 (2008-2009), 2009) and Stortingsmelding 24 Fremtidens barnehage (White Paper 24 - The Kindergarten of the Future) (St. meld. nr. 24 (2012-2013), 2013). These national documents (white papers) outline the Norwegian government's understanding of and goals for early childhood education and constitute a reference point for how ECEC institutions should develop in the eyes of the political institutions.

The fourth and last document is the Framework Plan for the Content and Tasks of Kindergarten ${ }^{9}$ (Norwegian Ministry of Education and Research, 2006/2011). This is a legally binding description of how preschools are to achieve the goals described in the Kindergarten Act and what should be included in the content of preschools. Being a framework, it allows some professional freedom when it comes to the adaptation of its guidelines; however, at the same time, it clearly states which areas are to be included in the content of early childhood education institutions in Norway and how these are to be implemented. The Framework Plan can often be found in physical form in early childhood education institutions as the main guideline for practice.

These documents, from the international network of the OECD to the Framework Plan, have been chosen as examples of the ongoing discourses around curiosity influencing early childhood educational practices. These types of documents are constantly under development and a revised Framework Plan is currently on its way. This article aims to contribute to new perspectives on how values and concepts are communicated in these types of documents.

\section{Methods and concepts}

The project's overall theoretical framework is the theory of practice architectures (Kemmis et al., 2014), which describes how to understand educational practices. In this approach, the official documents can be understood as "social-political

Nr. 19, 2016) has not been included in the analysis since the term curiosity is, apart being generally mentioned as one of many central concepts, only referenced to when quoting the existing Framework Plan or Kindergarten Act. Since the new version of the Framework Plan is not yet legally effective, this document has not been considered (although it is briefly mentioned in note 13).

${ }^{9}$ From now called the Framework Plan. 
arrangements"10 which are brought to the site of practices and "enable and constrain" interaction and pedagogical practices (Kemmis et al., 2014, p. 38). The educational sociologist Ozga (2000, 2009) focuses on the importance of analysing political documents which contribute to the construction of meaning and, therefore, have an implication in pedagogical practices. This is also the case for expressed value aspects of curiosity in the documents, which have an influence on educational practices insofar as they make certain pedagogical activities and practices more desirable than others. Therefore, it is necessary to examine such documents' representation and construction of values (Einarsdóttir, Purola, Johansson, Broström \& Emilson, 2014); in this case, the values associated with curiosity.

The method of analysis used here is document analysis. Generally speaking, this method can be described as the study of written material not created for the purpose of analysis (Thagaard, 2013, p. 59). The document analysis applied here uses theoretically informed qualitative content analysis with a concept-driven strategy (Schreier, 2012, p. 85). Qualitative content analysis is open about the influencing role of the researcher, involves a reflective research process and demands openness about how concepts used for categorisation are created (Schreier, 2012, p. 41).

The theoretical concepts this analysis is built on are the major value fields of early childhood education in the Nordic countries, as described by Einarsdóttir et al., (2014) and Johansson et al. (2015). The value aspects of curiosity in the documents will be analysed by connecting the use of the term curiosity to these value fields. In their description of values education, Johansson et al. (2015, p. 23) use the term value fields to describe areas of practice with a common value base. The fields are empirically developed in a study of documents and practices in Norway, Iceland, Sweden and Denmark and situated in the field of early childhood education. Three major value fields described in several Nordic curricula are: democracy, caring, and competence (Einarsdóttir et al., 2015). ${ }^{11}$ These value fields are not fully separated and are constructed analytical tools designed for developing a reference frame for discussing values education (Johansson et al., 2015, p. 19). They are used in this study to analyse the value aspects of curiosity by pointing out possible connections to these value fields.

In practice, this means that I use the term curiosity as a marker and the paragraphs where curiosity is mentioned become the units of analysis. The value fields as described by Einardóttir et al. (2014) are used as a starting point for examining how curiosity is associated with a network of values. Firstly, the meaning of the sentence (the immediate context) is analysed and interpreted. Secondly, the topic of the paragraph and its positioning are examined in relation to the rest of the document

\footnotetext{
${ }^{10}$ The theory of practice architecture also mentions cultural-discursive arrangements. As the documents also influence the general language used and discussions held on site, they could also be understood as pertinent to cultural-discursive arrangements.

${ }^{11}$ Johansson et al. (2015) point out several other value fields in their analyses of practices, including safety values, effective values or disciplining values.
} 
(wider contextual background). Furthermore, the documents are compared to each other to identify possible thematic patterns in terms of the value aspects of curiosity.

\section{Analysis}

The analysis will describe several value aspects of curiosity, which can be traced in the documents. The following quotes are chosen to represent main themes of these representations.

\section{Curiosity as a competence for gaining knowledge}

The first value connection found in several places is curiosity as seen as a value of competence. Competence values are described as "competencies and skills" (Johansson et al., 2015). Keywords described in this value field are: learning, development and growth (Einarsdóttir et al., 2014). When these keywords are used as a focus, several examples show representations of the value of curiosity as a competence value. The following quote from the Framework Plan is included in a chapter about learning, suggesting a strong connection to the process of learning. It also emphasises the importance of curiosity for lifelong learning.

The kindergarten shall foster children's curiosity, thirst for knowledge and desire to learn and shall help to provide a sound basis for lifelong learning and formation. (Norwegian Ministry of Education and Research, 2011, p. 29).

Stortingsmelding 24 also points out curiosity's role for further development:

Children who are encouraged to be curious and to increasingly understand and learn something new have a good starting point for further development. (St. meld. nr. 24 (2012-2013), 2013. Preface).

Here, curiosity is an element of the skills which are important in order to be prepared for (lifelong) learning and development. Curiosity is also mentioned in connection with how staff should approach the delivery of important knowledge (Norwegian Ministry of Education and Research, 2006/2011, p. 33). This description points to an understanding of curiosity as an instrument for delivering knowledge. Another quote shows a connection using the term learning outcome and it is stated that "children with the best abilities to express their curiosity will have the highest learning outcomes in kindergarten" (St. meld. nr. 41 (2008-2009), 2009, p. 76). Here, the term learning outcome points to a functional understanding of curiosity as part of a transaction with the goal of having an outcome. Curiosity as a basis for learning can also be found in the OECD document in the statement, that the curriculum should contain "cross-disciplinary learning activities that trigger children's curiosity" (OECD, 2011, p. 88). Children's participation through curiosity is seen to support this learning process. 
The analysis shows that curiosity is often presented with a competence value aspect. Curiosity is portrayed as a competence or skill needed to meet the challenge of lifelong learning, with children's acquisition of knowledge as the goal. Curiosity in these examples may, therefore, imply an instrumental value aspect. This leads to the question of which type of knowledge learning and curiosity are connected to in the documents?

\section{Learning areas connected to curiosity}

The Framework Plan divides its section about content into several learning areas such as art, culture and creativity and communication, language and text (Norwegian Ministry of Education and Research, 2006/11). Here, the term curiosity is used in three areas, the first being nature, environment and technology. Practitioners should approach these subjects by starting with:

... children's curiosity, interests and qualifications and help them to experience with all of their senses, observe and wonder about phenomena in the natural and technological world. (Norwegian Ministry of Education and Research 2011, p. 38).

The second knowledge area in which curiosity is mentioned is numbers, spaces and shapes. Staff are supposed to “support children's curiosity, love of mathematics and desire to explore mathematical connections" (Norwegian Ministry of Education and Research, 2011, p. 42). The term is not used in other knowledge areas such as art, culture and creativity or ethics, religion and philosophy. ${ }^{12}$ This suggests that curiosity here has a closer association to science than to other areas of knowledge. This impression is supported when looking at the short description of national centres in Stortingsmelding 24 (p. 76), which have the aim of supporting early childhood institutions with specialised knowledge. The term curiosity is mentioned solely by the Centre for Natural Science, while other centres, such as the Centre for Multicultural Education or Centre for Reading, do not use the term in their descriptions. Again, this points to a connection between curiosity and science in these documents.

Stortingsmelding 24 also provides an example of what is understood as good practice in its description of preparing for a trip: A picture of a stream is shown to the children, "arousing interest and curiosity" (p. 71) among them. The children's curiosity is evidenced by the questions they ask: "How long is the stream? Where does it start? Can they build a bridge, and what is needed so that the bridge is solid enough to walk on?" (St. meld. nr. 24 (2012-2013), 2013, p. 71). Children's curiosity is again connected to questions about a natural phenomenon. A similar connection between curiosity and scientific knowledge can also be found in the OECD document Starting Strong III: A Quality Toolbox for Early Childhood Education and Care. In the section in which numeracy is pointed to as a central knowledge area, it is stated that "staff can use children's existing knowledge and curiosity to develop mathematical

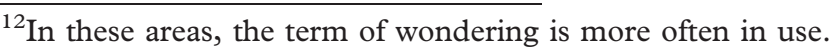


concepts, methods and language" (OECD, 2011, p. 86). Here too curiosity is excluded from the central learning areas of e.g. art and music. ${ }^{13}$

These examples show how curiosity in all the documents at the different organisational levels is often connected to natural science and mathematics. Practices using curiosity to support natural or mathematical sciences knowledge seem to be given special attention, making certain activities more desirable than others when it comes to supporting or triggering children's curiosity. An exception to the science connection is found in a third area of the Framework Plan (Norwegian Ministry of Education and Research, 2011, p. 40). This is the learning area called local community and society, wherein curiosity may be related to the value field of democracy.

\section{Curiosity as an element in democratic participation}

The value field of competence is not the only value field to which curiosity can be linked. Curiosity is also mentioned in connection with the value field of democracy, which has to do with issues such as "options and conditions for taking part in a community [...] and having the opportunity to influence" (Johansson et al. 2015, p. 20, my translation). This value field has been described as central in Nordic early childhood education and central keywords are: participation and equality (Einarsdóttir et al. 2014). The Framework Plan describes that:

... children's participation in the internal life of the kindergarten may be their first step towards gaining an understanding and experience of participating in a democratic society. Kindergartens shall help to ensure that children approach the world outside their families with trust and curiosity. (Norwegian Ministry of Education and Research, 2011, p. 40).

The learning area to which this quote refers is local community and society. Curiosity about the world and society beyond the family can, therefore, be interpreted as an element of being a participating democratic citizen. This interpretation is also supported by the fact that, according to the same section, early childhood institutions are responsible for supporting children in taking a curious and critical approach ${ }^{14}$ to information from the media (Norwegian Ministry of Education and Research, 2011 , p. 42). This critical and open approach could be seen as part of being a participating member of a democracy, a value advocated in these passages.

\footnotetext{
${ }^{13}$ In a new version of the Framework Plan, which will be effective from autumn 2017, curiosity is, in addition to the areas of science, nature and mathematics, also mentioned in the area of arts (Norwegian Ministry of Education and Research, 2017). This might be a first sign of the concept's associations being widened. In this new Framework Plan, curiosity is also used as often as wondering, while the earlier versions of the Framework Plan $(2006,2011)$ use wondering more often than curiosity.

${ }^{14}$ In the original Norwegian document the term curious/nysgjerrig is used, while the English translation uses inquisitive.
} 
Curiosity valued for learning and democracy

A similar value aspect can be found in the OECD document, but here curiosity is additionally connected to learning. In the national policy document Stortingsmelding 24 , curiosity is mentioned in the text's general description of a "good kindergarten". Here, the term curiosity is related to the two value fields of competence and democracy.

Creativity, curiosity, a willingness to cooperate and problem solving are just some of the qualities kindergarten emphasises. These are traits that promote an understanding far beyond actual skills. If we succeed in providing all kindergarten children with good care and good opportunities for learning and development, and simultaneously manage to address challenges early, we can help to ensure that individuals have a better life and a good basis for participation in future society. (St. meld. nr. 24 (2012-2013), 2013, p. 11).

In the quote, curiosity is mentioned alongside creativity and cooperation. It is also expressed that these character traits contribute to a wider understanding and may lead to a better life and participation in future society. This suggests that curiosity is, in some examples, being connected to both value fields: on the one hand, to a competence regarding future challenges and, on the other, to being a future participant in society. This parallel representation between learning as a competence and learning as a democratic value can also be found in the OECD document. Here, children's choices, self-determination and agency, for example through curiosity, become a supporting part of the learning process (OECD, 2011, p. 88). However, this section also includes the following statement:

Children's participation is not only important in order to facilitate effective learning of different curriculum elements but can be important in its own right and foster democratic values. (OECD, 2011, p. 88).

As curiosity is part of the process of participation, it is also linked to the value field of democracy. In addition to contributing to learning, it entails a democratic value aspect.

\section{Curiosity's connection to care}

Another major value field described by Einarsdóttir et. al (2014) is the value field of care, also described as the ethical value field, which "is ultimately about how human beings, children and employees in preschool take care of each other" (Johansson et. al, 2015, p. 20, my translation). Keywords connected to this value field are: caring, well-being, empathy, human dignity and recognition (Einarsdóttir et al, 2014 et al; Johansson et al, 2015, p. 20). An analysis of the documents shows that interpersonal relationships do not seem to be connected to the notion of curiosity in them. The only example of something resembling a connection between curiosity and the value field of care is an example from the Framework Plan, which describes that curiosity towards differences is important in today's diverse society (Norwegian Ministry of 
Education and Research, 2011, p. 20). However, apart from the example above, none of the documents suggest a value dimension of curiosity associated with general mutual care, such as in a relationship between children or between staff and child.

\section{Discussion}

The dominant focus on representations of curiosity's value aspect as a skill (for gaining knowledge often in the areas of science and mathematics) suggests that this is the prominent understanding. In some examples, curiosity's role in participating in or creating conditions for democracy points to a democratic value aspect. To sum up the findings of the analysis, it is suggested that curiosity in these documents is constructed as a value-loaded notion, whereby the primary value fields are competence (for learning) and (to a lesser degree) democracy.

The discussion will take a further look at these dominant representations, link them to current discussions on education and explore missing links and possible extensions. The first part describes the absence of negative connotations with regard to curiosity. The second discusses the value fields connected to curiosity in these documents. The third part explores a possible value aspect of curiosity that has not found its way into the documents. In the final part, I also suggest the possibility of an alternative understanding of curiosity as an intrinsic value.

\section{A romantic understanding of curiosity?}

Curiosity in these documents is presented in purely positive terms with almost no traces of curiosity's morally negative aspects or downsides found in the documents, which represent a predominantly positive understanding of curiosity. The negative sides of curiosity mentioned in texts from, for example, Early Christianity and which are still evident in some daily language, are not represented in the documents.

Since the documents do not mention the possible negative nature or moral pitfalls of curiosity, they could be criticised for leaving out the possible challenges associated with a superficial approach to knowledge. The possible triviality of curiosity described by Augustine as "the lust of the eyes", not for the sake of understanding, but just for the sake of seeing (1909, p. 197), might be an aspect which could be important for early childhood education. Ramos (2005, p. 275) argues for a rediscovery of Aquinas' differentiation between curiositas and studiositas in educational contexts. Studiositas is contrasted with the superficial and volatile curiositas and involves the ability to maintain our attention and to choose what we want to examine more closely. This might be an important skill as children encounter increasingly novel and complex stimuli. As the analysed documents do not mention the possible downsides of curiosity, such as restlessness, superficiality or the compromise of privacy, one might ask if they convey a romantic understanding of the notion. 
Focus on competence for learning in natural science and mathematical learning areas The bio-ethicist Loewy (1998) argues for a moral obligation in supporting curiosity and imagination and criticises societies and school systems for not nurturing these. According to the educational theorist Zuss (2012), this nurturing of curiosity is not a neutral endeavour but one dependent on power structures. This analysis has shown that, in the four documents, curiosity is understood primarily from the perspective of its competence value for learning and often where it pertains to the learning area of natural science. ${ }^{15}$ This may mean that an instrumental understanding of curiosity is increasingly being taken for granted. The roots of this connection between curiosity and natural science can be traced to the re-evaluation of curiosity as an instrument for improving society through scientific discovery during the Age of Enlightenment (Martens, 2003, pp. 73-85). Here, curiosity is described by the thinkers of the time as a starting point for improving society through the means of science. This bestows it with an element of purpose and outcome, which is in contrast to what Cicero described as a childish desire for knowledge "without the lure of profit" (1914, p. 449). This value dimension of curiosity seems to still dominate recent political documents in the field of ECEC.

In her comparative study of curricula, Vallberg-Roth (2014) describes a focus on learning and outcomes as a trend in the Nordic countries. An understanding of the main value aspect of curiosity as an instrument for gaining knowledge may be seen as being in line with this trend. Biesta (here in Swanson, 2010) criticises the idea of value-neutral education with a limited focus on outcome, claiming that it is commonly based on the assumption that schools need to focus on science and mathematics in order to meet the challenge of global competition. The analysed documents share a similar focus, as seen in the fact that curiosity is regarded as a competence leading to future benefits, and could, therefore, be interpreted as pointing to the same development. To challenge this development Biesta (2010b) reintroduces the need for defining what good education is and the recognition of its normative element. A narrow understanding of curiosity as a cognitive instrument for gaining (scientific) knowledge and preparing for (lifelong) learning leaves out several perspectives in the discussion of what could be regarded as good education in terms of curiosity. In the following, I will therefore explore possible lost links and extensions of the concept.

\section{(Re) establishing a lost connection to caring for others}

Despite the fact, as mentioned above, that the word curiosity has etymological roots in the Latin words cura, meaning to care, and curiosus, meaning to be concerned (amongst other meanings), the documents do not demonstrate an obvious connection to one of the major fields of ECEC: the value field of care. Maybe the shift to

\footnotetext{
${ }^{15}$ This is also in line with recent interest in the concept in the field of science education (Jirout \& Klahr, 2011; Luce \& Hsi, 2014; Gottfried, Preston, Gottfried, Oliver, Delany \& Ibrahim, 2016).
} 
the term nysgjerrighet, based on the German Neugier, with its negative connotations of greed and craving, has made this connection even less visible.

On the other hand, recent research from the field of positive psychology suggests a positive impact of curiosity on interpersonal relationships, (Kashdan, McKnight, Finchman \& Rose, 2011; Kashdan, DeWall, Pond, Silvia, Lambert, Finchman, Keller, 2013; Litman \& Pezzo, 2007). Others from the field of philosophy argue that curiosity involves values such as caring, and claim that this can even be a duty in some situations. Baumgarten describes the connection between curiosity and caring by calling curiosity fecundity as it fertilises care and concern (2001, p. 172). The possible connection between curiosity and empathy and that one cares and is attentive towards others when curious might, therefore, be a possible extension of the value aspects of curiosity. The inclusion of interpersonal caring makes it possible to challenge the view represented in the documents and to incorporate a wider understanding of curiosity by involving curiosity's relational value.

\section{A possible extension of the value aspects}

Analysing the documents for connections between curiosity and the established value fields of ECEC shows that, with a few exceptions, curiosity is given a prominent instrumental competence value with regard to learning and gaining knowledge. On the other hand, several psychologists from the field of positive psychology suggest a correlation between curiosity and well-being, defining curiosity as one of the ingredients of a fulfilled life (Kashdan, 2010; Silvia \& Kashdan, 2009). Therefore, in the last section of this discussion, I would like to mention a possible alternative value aspect of curiosity in the field of early childhood education: curiosity as an intrinsic value of existential importance.

In his article "Curiosity as a Moral Virtue", the philosopher Elias Baumgarten (2001) suggests that curiosity has existential importance. To Baumgarten (2001, p. 180), curiosity is a virtue due to the fact that it plays an important part in how we meet and care for other people. He describes it as the cornerstone for living well, as it is the antidote to apathy, indifference and boredom, and thereby leads to fundamental questions which can give meaning to human life. In this context, curiosity becomes a value in its own right, without serving an instrumental function for a future personal or societal benefit. Focusing on curiosity as a driving force for experiencing meaning rather than a competence for gaining knowledge, gives it an existential dimension. This approach suggests an alternative way of seeing and understanding curiosity in early childhood education. In addition to constructing curiosity as a neutral, instrumental, cognitive competence or skill and connecting it to the value field of democracy, another possible perspective should be added: an intrinsic value crucial to our existence as human beings. ${ }^{16}$ This involves taking an ontological approach towards pedagogy in contrast to an idea of pedagogy based on intervention and response

\footnotetext{
${ }^{16}$ This approach to curiosity has similarities to the critique of an instrumentalisation of play (Nome, 2015; Sundsdal \& Øksnes, 2015)
} 
(Farquhar \& White, 2014) and, therefore, allows curiosity to be described as an intrinsic value. By giving curiosity an ontological dimension rather than an instrumental one, curiosity could be understood as valuable in its own right without connecting it to the value of obtaining knowledge.

\section{Conclusion}

The analysis suggests that curiosity in the chosen documents is often connected to the value field of competence and understood as an instrumental tool for gaining (scientific) knowledge. Other possible connections to curiosity, such as its role in nurturing democratic values, are represented to a lesser degree, while other value aspects are missing. This article therefore suggests the possible re-establishment of the connection between curiosity and the value field of care and the possible extension of its understanding towards one as an intrinsic value of it.

Based on the analysis and the discussion, which describes existing, missing and possible alternative connections between the concept and its values, I have argued that the concept of curiosity is normative when contextualized in the field of ECEC. This means that by shifting from a cognitive and individualised perspective to a value perspective of curiosity, this article allows curiosity to be examined, not as a neutral trait or state, but as a value-loaded notion positioned in the field of education.

It must be noted that the analysis is limited to four documents. There is no definition of curiosity which can be interpreted as a single, adequate understanding. However, this analysis is a first look at the value aspects of curiosity that can be traced in the four official documents and its normative contextualisation. This invites reflection and awareness amongst legislators, educators and practitioners in the field of early childhood education. At the same time, official documents are just one area in which the value of curiosity is expressed. Further research into the practices of curiosity in the context of early childhood education may show what values preschool staff associate with curiosity, how its importance is legitimised and how it is constructed as a value-loaded notion in educational practices.

\section{References}

Afdal, G. (2014). Etiske og pedagogiske logikker. In G. Afdal, Å. Røthing \& E. Schjetne (Eds.), Empirisk etikk $i$ pedagogiske praksiser (pp. 30-49). Oslo: Cappelen Damm.

Amundsen, H. M. (2013). Barns undring. Bergen: Fagbokforlag.

Augustine, A. (1909). The Confessions of St Augustine. New York: Collier.

Baumgarten, E. (2001). Curiosity as a Moral Virtue. International fournal of Applied Philosophy, 15(2), $169-184$. doi: $10.5840 /$ ijap200115215

Benedict, B. (2001). Curiosity : A Cultural History of Early Modern Inquiry. Chicago: University of Chicago Press.

Berlyne, D. E. (1960). Conflict, Arousal, and Curiosity. New York: McGraw-Hill.

Biesta, G. (2009). Good Education in an Age of Measurement: On the Need to Reconnect with the Question of Purpose in Education. Educational Assessment, Evaluation and Accountability, 21(1), 33-46. doi: 10.1007/ s11092-008-9064-9

Biesta, G. (2010a). Why "What Works" Still Won't Work: From Evidence-Based Education to Value-Based Education. Studies in Philosophy and Education, 29(5), 491-503. doi: 10.1007/s11217-010-9191-x 


\section{Tracing Curiosity with a Value Perspective}

Biesta, G. (2010b). Good Education in an Age of Measurement: Ethics, Politics, Democracy. Boulder: Paradigm Publishers.

Blumenberg, H. (1988). Der Prozess der theoretischen Neugierde. Berlin: Suhrkamp.

Bø, I. \& Helle, L. (2008). Pedagogisk Ordbok. Universitetsforlaget: Oslo.

Chak, A. (2007). Teachers' and Parents' Conceptions of Children's Curiosity and Exploration. International fournal of Early Years Education, 15(2), 141-159. doi: 10.1080/09669760701288690

Chak, A. (2010). Adult Response to Children's Exploratory Behaviors: An Exploratory Study. Early Child Development and Care, 180(5), 633-646. doi: 10.1080/03004430802181965

Cicero. (1914). De finibus bonorum et malorum (H. Rackham, Trans.). Cambridge, MA: Harvard Press. doi: 10.4159/DLCL.marcus_tullius_cicero-de_finibus_bonorum_et_malorum.1914

Einarsdóttir, J., Purola, A.-M., Johansson, E., Broström, S. \& Emilson, A. (2015). Democracy, Caring and Competence: Values Perspectives in ECEC Curricula in the Nordic Countries. International fournal of Early Years Education, 23(1), 97-114. doi: 10.1080/09669760.2014.970521

Emilson, A. \& Johansson, E. (2011). The Desirable Toddler in Preschool: Communicated Values in Teacher and Child Interaction. In D. Berhelsen, J. Brownlee \& E. Johansson (Eds.), Participatory Learning and the Early years. Research and pedagogy (pp. 61-77). Oxford: Routledge.

Engel, S. L. (2015). The Hungry Mind: The Origins of Curiosity in Childhood. Cambridge: Harvard University Press.

Farquhar, S. \& White, E. J. (2014). Philosophy and Pedagogy of Early Childhood. Educational Philosophy and Theory, 46(8), 821-832. doi: 10.1080/00131857.2013.783964

Freire, P. (1998). Pedagogy of Freedom: Ethics, Democracy, and Civic Courage. Maryland: Rowman \& Littlefield. Focault, M. (1985). The History of Sexualitys. Vol 2. The use of pleasure. New York: Random House.

Fuller, R. (2006). Wonder: From Emotion to Spirituality. Chapell Hill: University of North Carolina Press.

Gottfried, A. E., Preston, K. S. J., Gottfried, A. W., Oliver, P. H., Delany, D. E. \& Ibrahim S. M. (2016). Pathways from Parental Stimulation of Children's Curiosity to High School Science Course Accomplishments and Science Career Interest and Skill. International fournal of Science Education, 38(12), 1972-1995. doi: 10.1080/09500693.2016.1220690

Griffith, F. (2014). The Talking Table: Sharing Wonder in Early Childhood education. In G. Judson, K. Egan \& A. Cant (Eds.), Wonder-full Education: the Centrality of Wonder in Teaching and Learning across the Curriculum (pp. 122-134). New York: Routledge.

Halstead, J. M. \& Taylor, M. J. (2000). Learning and Teaching about Values: A Review of Recent Research. Cambridge fournal of Education, 30(2), 169-202.

Inan, I. (2012). The Philosophy of Curiosity. New York: Routledge.

Jirout, J. \& Klahr, D. (2012). Children's Scientific Curiosity: In Search of an Operational Definition of an Elusive Concept. Developmental Review, 32(2), 125-160. doi: 10.1016/j.dr.2012.04.002

Johansson, E., Fugelsnes, K., Mørkeseth, E., Røthle, M., Tofteland, B. \& Zachrisen, B. (2015). Verdipedagogikk $i$ barnehagen. Oslo: Universitetsforlaget.

Kashdan, T. (2010). Curious? Discover the Missing Ingredient to a Fulfilling Life. New York: Harper Collins.

Kashdan, T. B., DeWall, C. N., Pond, R. S., Silvia, P. J., Lambert, N. M., Fincham, F. D. \& Keller, P. S. (2013). Curiosity Protects Against Interpersonal Aggression: Cross-Sectional, Daily Process, and Behavioral Evidence. Fournal of Personality, 81(1), 87-102. doi: 10.1111/j.1467-6494.2012.00783.x

Kashdan, T. B., McKnight, P. E., Fincham, F. D. \& Rose, P. (2011). When Curiosity Breeds Intimacy: Taking Advantage of Intimacy Opportunities and Transforming Boring Conversations. Fournal of Personality, 79(6), 1369-1402. doi: 10.1111/j.1467-6494.2010.00697.x

Kemmis, S., Wilkinson, J., Edwards-Groves, C., Hardy, I., Grootenboer, P. \& Bristol, L. (2014). Changing Practices, Changing Education. Singapore: Springer Singapore. Retrieved from http://link.springer.com/ 10.1007/978-981-4560-47-4

Kenny, N. (2004). The Uses of Curiosity in Early Modern France and Germany. Oxford: University Press.

Kenny, N. (1998). Curiosity in Early Modern Europe: Word Histories. Wiesbaden: Harrassowitz:

Kindergarten Act. (2005). Law on Kindergarten (Kindergarten Act). Retrieved from http://lovdata.no/dokument/NL/ lov/2005-06-17-64 Retrieved from https://www.regjeringen.no/globalassets/upload/kd/vedlegg/barnehager/ engelsk/act_no_64_of_june_2005_web.pdf Norwegian original version: http://www.udir.no/globalassets/ upload/barnehage/rundskriv/f-08-2006.pdf

Lawn, M. (2006). Soft Governance and the Learning Spaces of Europe. Comparative European Politics, 4(2-3), 272-288. doi: 10.1057/palgrave.cep.6110081

Litman, J. A. \& Jimerson, T. L. (2004). The Measurement of Curiosity As a Feeling of Deprivation. Fournal of Personality Assessment, 82(2), 147-157. doi: 10.1207/s15327752jpa8202_3 


\section{Soern F. Menning}

Litman, J. A. \& Pezzo, M. V. (2007). Dimensionality of Interpersonal Curiosity. Personality and Individual Differences, 43(6), 1448-1459. doi: 10.1016/j.paid.2007.04.021

Loewenstein, G. (1994). The Psychology of Curiosity: A Review and Reinterpretation. Psychological Bulletin, 116(1), 75-98. doi: 10.1037/0033-2909.116.1.75

Loewenstein, G. \& Markey, A. (2014). Curiosity. In R. Pekrun \& L. Linnenbrink-Garcia (Eds.), International handbook of emotions in education (p. 229-245). New York: Routledge.

Loewy, E. H. (1998). Curiosity, Imagination, Compassion, Science and Ethics: Do Curiosity and Imagination Serve a Central function? Health Care Analysis, 6(4), 286-294. doi: 10.1007/BF02678364

Luebbe, H. (1980). Philosophie nach der Aufklärung. Von der Notwendigkeit pragmatischer Vernunft. Düsseldorf: Econ.

Luce, M. R. \& Hsi, S. (2014). Science-Relevant Curiosity Expression and Interest in Science: An Exploratory Study. Science Education, 99(1), 70-97. doi: 10.1002/sce.21144

Manson, N. C. (2012). Epistemic Restraint and the Vice of Curiosity. Philosophy, 87(2), 239-259.

Martens, E. (2003). Vom Staunen, oder, die Rückkehr der Neugier. Ditzingen: Reclam.

Menning, S.-F. (2016). Nysgjerrig på nysgjerrighet! Å sette fokus på nysgjerrighetsprosesser. In T. Gulpinar, L. Hernes \& N. Winger, Blikk fra barnehagen (pp. 163-172). Bergen: Fagbokforlaget.

Müller, G. (1984). Neugier. In J. Ritter, og K. Gründer (Eds.), Historisches Wörterbuch der Philosphie (Band 6) (pp.732-736). Darmstadt: Wissenschaftliche Buchgesellschaft.

Nabokov, V. (1947/1973). Bend Sinister. New York: McGraw-Hill.

Nome, D. (2015). Kindergartens- Schools without Recess: The Consequence of an Instrumentalist Notion of Play. In S. Hillen \& C. Aprea (Eds.), Instrumentalism in Education - Where is Bildung left? (pp. 15-27). Muenster: Waxmann.

Norwegian Ministry of Education and Research and Research. (2006/2011). Framework Plan for the Content and Tasks of Kindergarten. Norwegian Ministry of Education and Research and Research. Retrieved from https://www.udir.no/Upload/barnehage/Rammeplan/Framework_Plan_for_the_Content_and_Tasks_of_ Kindergartens_2011_rammeplan_engelsk.pdf?epslanguage $=$ no

Norwegian Ministry of Education and Research and Research. (2017). Framework Plan for the Content and Tasks of Kindergarten. Norwegian Ministry of Education and Research and Research. Retrieved from: https:// lovdata.no/static/lovtidend/ltavd1/2017/sf-20170424-0487.pdf

OECD. (2011). Starting Strong III. Paris: OECD Publishing. Retrieved from http://www.oecd-ilibrary.org/content/ book/9789264123564-en

Opdal, P. M. (2001). Curiosity, Wonder and Education seen as Perspective Development. Studies in Philosophy and Education, 20(4), 331-344. doi: 10.1023/A:1011851211125

Ozga, J. (2000). Policy Research in Educational Settings: Contested Terrain. Buckingham: Open University Press.

Ozga, J. (2009). Governing Education through Data in England: From Regulation to Self-Evaluation. fournal of Education Policy, 24(2), 149-162.

Piaget, J. (1969). Das Erwachen der Intelligenz beim Kinde. Stuttgart: Ernst Klett.

Pons (n.d.). Curiositas/curiosus. In Online Wörterbuch. Retrieved 10.01.2017 from http://de.pons.com/\%C3\% BCbersetzung? $\mathrm{q}=$ curiosity $\& \mathrm{l}=$ dela\&in $=\& \mathrm{lf}=\mathrm{la}$

Ramos, A. (2005). Studiositas and Curiositas: Matters for Self-Examination. Educational Horizons, 83(4), 272-281.

Schreier, M. (2012). Qualitative Content Analysis in Practice. London: SAGE.

Silvia, P. J. \& Kashdan, T. B. (2009). Interesting Things and Curious People: Exploration and Engagement as Transient States and Enduring Strengths. Social and Personality Psychology Compass, 3(5), 785-797. doi: $10.1111 / j .1751-9004.2009 .00210 . x$

St. meld. Nr. 41 (2008-2009). (2009). Kvalitet $i$ barnehage (Quality in the Kindergarten). Oslo: Kunnskapsdepartement. Retrieved from https:/www.regjeringen.no/contentassets/78fde92c225840f68bce2ac2715b3def/no/pdfs/stm200820090041000dddpdfs.pdf

St. meld. Nr. 24 (2012-2013). (2013). Fremtidens barnehage (The Kindergarten of the Future). Oslo: Ministry of Education and Research. Retrieved from https://www.regjeringen.no/contentassets/ 2e8ad98938b74226bc7ff395839434be/no/pdfs/stm201220130024000dddpdfs.pdf

St. meld. Nr. 19 (2015-2016). (2016). Tid for lek og laring (Time for Play and Learning). Oslo: Ministry of Education and Research. Retrieved from https://www.regjeringen.no/contentassets/cae152ecc6f 9450a819ae2a9896d7cf5/no/pdfs/stm201520160019000dddpdfs.pdf

Sundsdal, E. \& Øksnes, M. (2015). Til forsvar for barns spontane lek. Nordisk Tidsskrift for Pedagogikk og Kritikk, 1(0). doi: 10.17585/ntpk.v1.89 
Swanson, D. M. (2010). Value in Shadows: A Critical Contribution to Values Education in Our Times. In T. Lovat, R. Toomey, \& N. Clement (Eds.), International Research Handbook on Values Education and Student Wellbeing (pp. 137-152). Dordrecht: Springer Netherlands. Retrieved from http://link.springer. com/10.1007/978-90-481-8675-4_8

Thagaard, T. (2013). Systematikk og innlevelse: en innføring i kvalitativ metode (4. utg.). Bergen: Fagbokforlaget. Thornberg, R. (2014). Värdepedagogik: En introduktion. In R. Thornberg \& E. Johansson (Eds.), Värdepedagogik: Etik och demokrati i förskola och skola. Stockholm: Liber.

Vallberg Roth, A. (2014). Nordic Comparative Analysis of Guidelines for Quality and Content in Early Childhood Education. Fournal of Nordic Early Childhood Research. 8(1), 1-30. doi: 10.7577/nbf.693

Van Deth, J. \& Scarbrough, E. (1998). The Concept of Values. In J. Van Deth \& E. Scarbrough (Eds.), The Impact of Values (pp. 21-46). Oxford: University Press.

Voss, H.-G. \& Keller, H. (1983). Curiosity and Exploration. New York: Academic Press.

Zuss, M. (2012). The Practice of Theoretical Curiosity. Dordrecht: Springer Netherlands. Retrieved from http:// link.springer.com/10.1007/978-94-007-2117-3 